\title{
ETHICAL AND LEGAL RESTRICTIONS ON CONTRACT AND CORPORATE PRACTICE OF MEDICINE
}

\author{
Joseph LAuper*
}

In response to profound social, economic and technological changes experimentation with new forms ${ }^{1}$ of medical practice has begun on a nationwide basis. These new forms might be described as deviations from a traditional pattern which was molded by a close, confidential relationship between doctor and patient, entered into and continued by virtue of a "free choice" on both sides, and based economically upon a fee charged for an individual service. Where the patient is met no longer by an individual physician but by a group, usually specialists united in a "clinic," the first deviation from the pattern is present: i.e., "group practice." Here the economic basis of the relationship is'still the individual fee. A second deviation, often combined with, but distinguishable from, the first, is the intervention of a third party, an individual or organization agreeing with a physician or a group of physicians for the future treatment of a group of patients. The patient no longer contracts directly with the physician. Practice carried on pursuant to such third-party agreements is termed "contract practice"2 by the medical profession. It is these agreements which form the basis of most medical care plans providing for risk-sharing prepayment by groups of patients.

These plans utilizing either "group" or "contract" practice or both, must run the gantlet of restrictive rules derived from medical ethics or law. Of the major restrictions two will be considered here: the ethical rules governing "contract practice," and the legal rules governing "corporate practice of medicine."

The ethical and the legal rules alike spring from a time when the traditional pattern was the universal ideal. Their main purposes were to protect the public from quackery and also to preserve the traditional detachment of the profession from commercialism. The danger of lay and even professional efforts to import commercial methods into the medical field has been a real one in the past, and it would be idle to

- Graduate in law, University of Tübingen, 1932. Now a member of the third-year class in Duke University School of Law. Editor-in-chief of the Duke Bar Association Journal.

${ }^{2}$ See, gentrally, Medical Care for the American People: Finaz Report, Comm. on Costs of Medical Care (1932); New Plans of Medical Service (Julius Rosenwald Fund, 1936); AMa Bureav of Med. Econ., New Foras of Medical Practice (undated); Bernheim, Medicine at the Crossronds (1939); Note, Group Practice terstus the AMA (1938) 47 YALE L. J. II93.

2 Sec Principles of Medical Ethics of the AMA, c. III, art. VI, \$2, published in American Med. Directory (isth ed. 1938) is. 
assume that the risk no longer exists. ${ }^{3}$ Now, as then, the ethical rules and the medical practice acts fulfill an important task in thwarting such anti-social efforts. But the problem today is more difficult. The courts, in interpreting the medical practice acts face a dilemma: too restrictive an interpretation may block socially desirable experimentation, too liberal rulings may open the door to commercialized schemes. It is important, therefore, in this period of transition, to examine the legal principles involved, and the bases for their interpretation. The same, mutatis mutandis, holds true of the professional ethics of the medical profession. The latter are embodied in the code of ethics of the American Medical Association and constitute the special law of a group, made, interpreted, enforced by the group or its subdivisions. The code was adopted ${ }^{4}$ in its present form in Igाz by the AMA's legislature, the House of Delegates, and entitled "Principles of Ethics." It is applied and interpreted in the grievance committees of the component county and constituent state societies. From these committees, which are, in effect, professional courts, appeal lies to the Judicial Council of the AMA, the medical Supreme Court. That rulings and decisions of these professional courts do not lack effective sanction is evident from the fact that the ultimate penalty, expulsion ${ }^{5}$ from his professional organization, may often spell economic ruin to the expelled member, for he may no longer be able to treat his patients in good hospitals.

Seldom have courts interfered with this professional jurisdiction if the defendant has been accorded a fair hearing. This non-interference is based on the notion that private organizations, as the AMA, may lay down rules ${ }^{6}$ which must be followed by those who wish to be or remain members. The only limitation on this group autonomy is that the rules may not run counter to "public policy" as conceived by the reviewing court. ${ }^{7}$ But these professional rules have a wider importance. They have often a decisive bearing on judicial decisions. Legal reasoning is seldom, if ever, self-sufficient or self-sustaining. It draws its driving force and persuasion from other and deeper sources, and one of these is ethics. Thus, in the litigation of questions involving the practice of medicine the ethical rules may often be more decisive than mere logical, legal argumentation. It is against this backdrop of judicial and professional power and responsibility that the following discussion should be viewed.

\section{Ethical Restraints on Contract Practice}

The history of contract practice ${ }^{8}$ can be traced back over a period of almost 90 years. It originated as early as the middle of the last century when railroads, mining

3 See Medical Care for the American People, supta note 1 , at 47.

- (Igr2) 58 J. A. M. A. I907.

${ }^{-}$Sec cases of recent expulsions cited in Note (1938) 47 YarE L. J. I193, n. r4.

- $C$. Weyrens v. Scotts Bluff County Med. Society, 277 N. W. 378 (Neb. 1938); Harris v. Thomas, 217 S. W. 1068 (Tex. App. 1920). As to rules on contract practice, see Irwin v. Lorio, I69 La. 1090, I26 So. 669 (1930); Porter v. King County Med. Society, 186 Wash. 410, 58 P. (2d) 367 (1936).

"See cases cited supra, note 6 .

${ }^{8}$ See, generally, Leland, Some Phases of Contract Practice, (AMA Bureau of Med. Econ., I932); Leland, Contract Practice, Proceedings of the Annual Congress of Medical Education, Hospitais 
and lumbering industries met the need of providing medical care for their employees under "frontier" conditions by hiring salaried physicians. The practice spread. When in the beginning of this century workmen's compensation laws began to be enacted, some states built the existing pattern of this industrial contract practice into their own scheme of reform, giving it not only formal legal sanction but new impetus. The tendency towards expansion was further strengthened by the steady growth of industrialization. Another, independent root is found in mutual benefit associations in the cities which furnished their members hospitalization and medical care for which they paid in form of membership fees.

From the very outset, the medical profession raised grave ethical objections against this method of supplying medical care, especially within the industrial field where the danger of abuses was greatest. Underpayment of the contract physician, restriction of free choice, insufficient treatment, lay control, interference with the confidential doctor-patient relationship, underbidding between physicians and generally unfair competition with the independent practitioner were mainly complained of. Intimations ${ }^{9}$ were made that contract practice was justifiable only in cases of necessity, i.e., where independent practitioners are not available. The enactment of the workmen's compensation laws did not silence these complaints since they did not prevent the continuance of some of these abuses in this field into the present time as a recent comprehensive study indicates. ${ }^{10}$

Despite the abuses, actual or possible, connected with contract practice, it spread far beyond the industrial field with its special problems. Prior to 1912, however, the code of ethics had not dealt specifically with it. Whatever objections were raised at that time, were based on more general principles. But when in 1912 the present version of the "Principles of Ethics" was adopted, ${ }^{11}$ a new section ${ }^{12}$ was inserted under the heading of "Contract Practice" which provided:

"It is unprofessional for a physician to dispose of his services under conditions that make it impossible to render adequate service to his patients or which interfere with reasonable competition among the physicians of a community. To do this is detrimental to the public and to the individual physician, and lowers the dignity of the profession."

This rule remained unchanged until x934. The emphasis upon two major objections, danger of inadequate service and of unreasonable competition among physicians, illustrates clearly the dual aspect of the problem in which ethical and economic considerations are interwoven. But the question was not settled by this broad rule. Contract practice continued to expand. In I939, the AMA's authority on contract practice reported ${ }^{13}$ that there are:

" 75 group hospitalization plans, some 54 hospital insurance companies, . . at least 2000 medical care services, at least 500 medical and hospital benefit organizations, about 24

AND LICENSURE OF tHE AMA, I937, 75, 82 (hereafter cited as "Proceedings"); Economics AND THE Ethics of Medicine (AMA Bureau of Med. Econ., 1937).

- Cf. Leland, Contract Practice (AMA Bureau of Med. Econ. 1932) 17.

${ }^{10}$ Dodd, Administration of Workmen's Compensation (i936) 490-493.

${ }^{21}$ Supra note 4. $\quad{ }^{12}$ Supra note 2.

1s Leland, Trends in the Distribution of Medical Care, ProceEdiscs, 1939, 7r. 
union sick benefit funds and fraternal organizations, . . . about 300 private group clinics, at least 300 college and university students health services, ... an unknown number of plans designed to assist portions of low income farm families . . .; in addition, the physicians themselves are operating more than 150 medical care plans and are considering the organization of 120 more. ..."

This growth of contract practice was accompanied within the profession by discussion and dissension mounting with the stress of the depression years. The Judicial Council had occasion to warn 14 that "many of the members of the AMA are straining at the ethical leashes which curb their desires." Finally, the need for further development of the rule led to a number of amendments adopted in I934.

One of them, though general in form, has a direct bearing on contract practice. It provides, under the title "Direct Profits to Lay Groups":15

"It is unprofessional for a physician to dispose of his professional attainments or services to any lay body, organization, group or individual, by whatever name called, or however organized, under terms or conditions which permit a direct profit from the fees, salary or compensation received to accrue to the lay body or individual employing him. Such a procedure is beneath the dignity of professional practice, is unfair competition with the profession at large, is harmful alike to the profession of medicine and the welfare of the people, and is against sound public policy."

This section, aimed against commercial exploitation of medical services, would clearly not prevent non-profit organizations from engaging in contract practice even if they should accumulate an operating surplus which would be used as a reserve.

More pertinent to the specific problem, however, is another amendment ${ }^{16}$ which provided:

"By the term 'contract practice' as applied to medicine is meant the carrying out of an agreement between a physician or a group of physicians, as principals or agents, and a corporation, organization, political subdivision or individual, to furnish partial or full medical services to a group or class of individuals on the basis of a fee schedule or for a salary or a fixed rate per capita.

"Contract practice per se is not unethical. However, certain features or conditions if present make a contract unethical, among which are: $I$. When there is solicitation of patients, directly or indirectly. 2. When there is underbidding to secure the contract. 3. When the compensation is inadequate to assure good medical service. 4. When there is interference with reasonable competition in a community. 5. When free choice of a physician is prevented. 6. When the conditions of employment make it impossible to render adequate service to the patients. 7 . When the contract because of any of its provisions or practical results is contrary to sound public policy.

"Each contract should be considered on its own merits and in the light of surrounding conditions. Judgment should not be obscured by immediate, temporary or local results. The decision as to its ethical or unethical nature must be based on the ultimate effect for good or ill on the people as a whole."

This amendment removes any doubt that hitherto may have existed as to the ethical status of contract practice generally. It is now impossible to deny ethical

14 Report of the Judicial Council (1934) 102 J. A. M. A. 1497.

${ }^{28}$ Now c. III, art. VI, 55 , stipra note 2.

${ }^{10}$ Now C. III, art. VI, \$3, supra note 2. 
recognition to an agreement simply because it involves contract practice. To that extent the provision restricts complementary rules ${ }^{17}$ which component and constituent societies might adopt. Since they may not contradict the rules of the AMA, any blanket provision ${ }^{18}$ against contract practice would be unconstitutional and void. It is likewise to be noted that contract practice has not been restricted to "emergency" situations where the "usual conditions of employment," i.e., an individual doctorpatient agreement, cannot be created.

This shift in position-essentially a change in emphasis-suggests a need to resolve a conflict of ethical ideals or values. The ideal of the individual doctor-patient relationship conflicted with the ideal of extending medical care to all in so far as that could be achieved only by contract practice. It is a familiar function of ethical rules to guide choice where a dilemma is unavoidable. They fix a scale or hierarchy of values which changes with changing times and circumstances. Thus, precedence is now accorded the extension of medical care through contract practice but only if certain basic conditions, associated with the individual relationship ideal, are complied with. It must be noted, however, that this enumeration of "features or conditions" which taint an agreement as unethical, is not exclusive. Some are of a kind determinable by facts which are more or less easily ascertainable or measurable. Solicitation, underbidding, inadequate compensation, perhaps even presence or absence of free choice of physician are among them. But others are far less tangible. When is there "interference with reasonable competition in a community"? What are the standards of reasonable competition? When, furthermore, is a contract contrary to sound public policy? May that be the case even if all the preceding objectionable features have been eliminated? The code gives ${ }^{10}$ a general hint: "each contract should be considered on its own merits and in the light of surrounding conditions. Judgment should not be obscured by immediate, temporary or local results. The decision as to its ethical or unethical nature must be based on the ultimate effect for good or ill on the people as a whole." This caveat raises the question whether final effects can be determined other than in terms of local results which, as the "Principles" warn, should be disregarded as "obscuring the judgment."

In 1937 a further amendment ${ }^{20}$ was added. It provided:

The phrase "free choice of physician" as applied to contract practice is defined to mean that degree of freedom in choosing a physician which can be exercised under usual conditions of employment between patient and physician when no third party has a valid interest or intervenes. The interjection of a third party who has a valid interest or who intervenes does not per se cause a contract to be unethical. A "valid interest" is one where, by law or necessity, a third party is legally responsible either for cost of care or for indemnity. "Intervention" is the voluntary assumption of partial or full responsibility for medical care. Intervention shall not proscribe endeavor by component or constituent medical societies to maintain high quality of service rendered by members serving under

\footnotetext{
${ }^{27}$ Cf. warning in the Report of the Judicial Council (1937) 108 J. A. M. A. 1539.

${ }^{18}$ But cf. Ill. State Med. Society ruling that lodge contract practice is unethical, (1937) 109 J. A. M. A., Organizational Section, $84 \mathrm{~b}$.

${ }^{29}$ Supra note 16.

${ }^{20}$ Now c. III, art. VI, $\S_{3}$, supra note 2.
} 
approved sickness service agreements between such societies and governmental boards or bureaus and approved by the respective societies.

The provision, rather obscurely phrased, ${ }^{21}$ seems to indicate that the ideal of freedom of choice has been abandoned in a case where "a third party has a valid interest or intervenes."22 The third party thus privileged must have either of the following qualifications ( $I$ ) it must be legally responsible for the patient, or (2) it must have agreed to a voluntary assumption of partial or full financial responsibility. But when may a party, by law or necessity, be legally responsible? It can obviously not mean when a party has bound itself by contract. For this would permit restriction of "freedom of choice" in all cases of contract practice and thus render the entire provision nugatory. The elimination of that responsibility based on contract would leave governmental departments, subdivisions of the states, perhaps employers under the workmen's compensation laws, as such privileged parties for their responsibility rests directly on law. This answer does not cover the case where a party is legally responsible "by necessity." Presumably, the phrase aims at a situation where a legal duty to give medical care arises only if the patient cannot get it otherwise, as, e.g., the lumbering company might be responsible for a woodsman sent to a remote lumber camp.

When is there a "voluntary" assumption of financial responsibility? Again, it cannot mean a party that is not obligated to assume financial responsibility but assumes it of its own accord, for this interpretation would permit all contract schemes of private organizations to restrict "freedom of choice" which cannot be intended. The term "voluntary" would rather point to charitable institutions which render their services gratuitously. This interpretation accords with current usage of the term by the medical profession.

If this interpretation is correct, the amendment relaxed the rules as to "freedom of choice" somewhat in favor of governmental and charitable contracts, probably also in the situations covered by the workmen's compensation acts. It has tightened them, however, in all other agreements, by requiring practically absolute freedom of choice. It is very doubtful whether many of the plans actually operating comply with this strict requirement. It must be further noted that even in plans where this freedom is absolute, the very existence of the plans leads to an important qualification: under many plans, the patient may, for purposes of control, be brought in contact with a supervising physician. This is especially true when serious and costly operations are contemplated. If plans, based on private initiative, are to succeed there may be need for some form of approach to the public. Dignified solicitation ${ }^{23}$ may

${ }^{21}$ No official comment was published at the time of adoption. See (1937) 108 J. A. M. A. 2225.

22 The statement that the "interjection of the third party" does not per se make a contract unethical, would be a needless repetition of the general principle that contract practice is not unethical per se unless it means that in these cases even the absence of free choice will not render the contract unethical per se.

${ }^{23} \mathrm{Cf}$. Privciples of Medical. Ethics, c. III, art. $\mathrm{I}, \S_{4}$ : "Solicitation of patients by physicians as individuals, or collectively by groups by whatsoever name these be called, or by institutions or organizations, whether by circulars or advertisements, or by personal communications, is unprofessional. This does not prohibit ethical institutions from a legitimate advertisement of location, physical surroundings, and special 
have to be recognized within clearly defined limits. These illustrations show that the recognition of contract practice will raise new and difficult ethical problems.

The present rules are doubtless not the ultimate answer. As they stand, it must be admitted that the grant of discretion to the grievance committees is, for purposes of administration, unlimited. The final control over any agreement seems to be left with the local committees or state appeal boards which may or may not seek advice of the Judicial Council. Formal appeals to this body, as contrasted with informal inquiries and replies, seem to be rare. The comparative lack of publicity given to these "internal affairs" prevent ascertainment of the application of the rules on "contract practice" to individual cases. Litigation over these matters in ordinary courts is uncommon and as long as the courts feel that these rules are not violating "public policy," litigation would seem useless.

\section{Legal Restrictions on the "Corporate Practice" of Medicine}

The corporate device ${ }^{24}$ is frequently encountered in the sphere of medical activities. Proprietary, charitable and university hospitals, where patients are treated by salaried physicians, have long been familiar. With the spread of industrial contract practice, hospitals were built by, physicians engaged therein, and organized as corporations. Large industrial corporations, railroads, etc., set up their own hospitals. and engaged medical staffs for their employees. More recently, the device has been used for purposes of organizing group practice in the form of incorporated clinics requiring capital investment by the associated doctors. These "plant" investments have increased with the ever-growing need for complicated, expensive equipment. In addition, expected or actual advantages under the tax laws, convenience of transfer in the case of personnel changes, avoidance of risk of liability for malpractice incurred by colleagues, continuity of the corporate existence, all such considerations may have contributed to the choice of this form so familiar to the business world. ${ }^{25}$

Many of these "clinics" dealt with the individual patient as would an individual practitionèr. Some however, engaged in either industrial or general contract practice. Laymen organized corporations for profit which sold medical service contracts to the public. The services were to be supplied by doctors who had contracted with the corporation. On a higher plane, insurance companies began to write health policies providing either for the payment of a doctor's bill or the supply of medical services in kind. To the familiar incorporated fraternal or mutual benefit organizations, which included medical services among their benefits, have recently been added nonprofit cooperatives organized by lay groups for the specific purpose of supplying their members with medical care on a prepayment basis.

\footnotetext{
class-if any-of patients accommodated." See also proposal to permit advertising of plans sponsored by state societies (1938) III J. A. M. A. 1210, 1215.

"See, generally, I Fletcher, Corporations (Perm. ed. 1931) \$97, 6 id. \$2525; Davis, Do Corporttions Practice Medicine? Procendings 1932, 88 et seq.; Warnshuis, The Practice of Medicine by Corporations Proceedings 1932, 72; Levy and Mermin, Cooperative Medicine and the Law (1938) I Nat. LAwYers Gurzd Q. 194; Note, Right of Corporation to Practice Medicine (1938) 48 YALE L. J. 346; Notes (1939) 7 Geo. WASH. L. Rev. 120; (1939) 37 Mich. L. Rev. 96I; (1939) I7 N. C. L. Rev. I83.

${ }^{25}$ Private Group Cinics: Comm. on Costs of Medical Care, Pub. No. 8 (1931) 19, 20.
} 
Despite this widespread use of the corporate device its legal status is by no means clear. The corporation statutes which usually. provide that a corporation may be formed for any "lawful" purpose do not give an explicit answer since they throw no light on the "lawfulness" of the purpose. The legality of the purpose must depend on the applicability of the medical licensure acts. A literal reading of their provisions ${ }^{28}$ indicates that they were aimed to regulate only the conduct of individuals engaging.in medical activity. As they do not say explicitly what shall be the effect of the employment of such an individual by a corporation, there results a "gap" in the law which must be closed, in the absence of specific legislative regulation, by judicial interpretation. In other words, the problem is reduced to one of public policy to be determined by the courts.

Any examination of this policy problem calls for inquiry into the considerations governing the regulation of the professions. Basic among these is the grave difficulty raised by the professional man's tremendous power over the lay client. In ordinary dealings, the layman's common sense and experience suffice to check undue encroachments on his interests by the other side. This check is absent when he deals with professional men to whom, often enough, his health or economic existence must be entrusted; whatever the layman's experience may be, the lawyer's or physician's conduct is, to a large extent, beyond the reach of his judgment. Here, the "policing" function of the licensure statutes fulfils an important task. Unfit practitioners are kept out and those who are admitted are subjected to legal supervision, supplemented by professional discipline. Why then should the appearance of a corporation in the professional field create difficulty, provided only duly licensed physicians or lawyers are entitled to act as its agents? They will be subjected to the double supervision exercised over the independent professional man: by state authorities under the licensure acts, by professional bodies under the ethical codes. However, this reasoning overlooks one fact: both licensure states as well as enforceable rules of ethics reach or "police" only the most egregious offenses committed in the wide area of professional activities. The remainder is and must be left to the conscience of the individual. As he faces the ever-present temptation of furthering, without risk of discovery or punishment, his own interests over those of an unwitting client, ethical rules are expected to check his desires. Experience has shown that this check may prove too weak, but its necessity and average efficacy cannot be doubted. It is here that the appearance of the corporation raises a real problem. By the introduction of a third party, an outside interest, the strain on the individual is increased. For the normal temptation has been heightened as the professional man's own interest, hitherto exclusively personal, becomes weighted by the existence of the third party. He may now consciously or subconsciously subordinate the client's interest even where he would otherwise not have done so. His loyalty is divided. ${ }^{27}$ In this regard,

${ }^{20}$ See, e.g., N. C. CODE (Michie, r939) c. IIo, art. I.

${ }^{27}$ See, e.g., People ex rel. State Bd. of Med. Examiners v. Pac. Health Corp., 12 Cal. (2d) 156,158 ; 82 P. (2d) 429, 430, (1938); Dr. Allison, Dentist, Inc. v. Allison, 360 Ill. 638, 642, 196 N. E. 799, 800 (1935); Neill v. Gimbel Bros. Inc., 330 Pa. 213, 219, I99 Atl. I79, I8r (1938). 
it is obvious that the objections to corporate practice are not overcome by pointing to the legal and professional supervision over its licensed agents. ${ }^{28}$ For these "external" safeguards do not operate within the sphere of individual motivation where their sanctions are unenforceable.

To the problem of the effect of the corporate employment on the practitioner's motivation must be added a second problem. It arises from the fact that corporate organization necessarily implies delegation of functions. Even if usually strictly medical functions, as surgery, etc., are left to licensed physicians, there is a penumbra of activities usually reserved to the practitioner in independent practice but likely to be delegated to lay personnel in a corporation. Certainly, a point may be reached where this delegation is clearly undesirable. Where is the line to be drawn? Should a lay board be delegated to impose general conditions on treatments to be rendered? What, if the same function is entrusted to a board of physicians? Can' the conclusion of the agreement, fixing of fees, extension of credit thus be delegated? Obviously, any delegation made to laymen will exempt conduct from the influence of medical ethics as these rules apply to the physician's entire conduct whether technically practice or not.

To seek a simple solution for both problems in an outright condemnation of medical services rendered within a corporate framework, as many dicta seem to indicate, ${ }^{20}$ is, of course, possible. This position, however, would disregard substantial distinctions in the types of interest presented in corporate form. Three types of corporations might here be differentiated.

A. The first type would include those corporations where the interest of the corporation is opposed to that of the patient only in a limited sense: any services to him will necessarily reduce the amount of services available to the class of patients which it serves. Here might be grouped: (a) charitable institutions of every description, (b) industrial organizations ${ }^{30}$ where a paternalistic entrepreneur has allotted a budget for medical care of his employees; (c) incorporated fraternal and benefit organizations, (d) the recent group health organizations on a cooperative basis. ${ }^{81}$ The third interest presented by the corporate device in the last two instances may, in disregard of the corporate entity, be considered as identical with that of the patient as a member of the organized group.

B. In the second type of corporation the interest of the entity does not essentially differ from that of the individual licensee. Its chief representative ${ }^{31 "}$ is "group practice" carried on in the form of an incorporated clinic. The disregard of the corporate entity would reveal, not the identity of patient and corporation, as in the previous illustration, but of physician and corporation. As long as the medical control is unimpaired, all responsible officers are within the sphere of professional, i.e., ethical, motivation.

${ }^{28}$ Contra: Note (1938) 48 YALE L. J. $346,348,350$.

${ }^{10}$ See the numerous cases cited 102 A. L. R. 343 (1936); 103 A. L. R. 1240 (1936); I19 A. L. R. 1290 (1939).

${ }^{\text {so }}$ Here, the rendition of medical services within a corporate framework is merely incidental to an economic enterprise with a wholly different main purpose.

${ }^{31}$ See Group Health Ass'n v. Moor, 24 F. Supp. 445 (D. C. 1938).

312 Another is the "one-man corporation." For examples, see the last two cases cited in note 45 , infra. 
C. The third type comprises lay-controlled business corporations, admittedly organized for profit, insurance companies, etc. Here, plainly, any service rendered to the patient may reduce the possible profit margin of the corporate enterprise, a "third interest" which is alien to doctor and patient alike and which is characterized by the need for profits and return of invested capital. This basic need of its corporate life must condition all its relations and will tax greatly the motivating strength of the ethical rules even where there is complete absence of lay interference with medical activity. Economic realities need no tangible medium to assert themselves.

It will be realized that this classification is only tentative. ${ }^{32}$ In reality, the lines will often be blurred. The industrialist who makes profits ${ }^{33}$ on the contributions exacted from his employees for medical care, the "medical group" operating with high pressure business methods, are ready illustrations. Nonetheless, the attempted classification is based on real distinctions which reflect varying degrees of strain on the practitioner's motivation and of impairment of the doctor-patient relationship. The problem remains whether these distinctions may offer standards for future judgments which will carefully discriminate between corporation and corporation. ${ }^{34}$

The legal approach to this question has been made in terms of "corporate practice." This phrase conceals faulty analysis in which, although the corporation's inability to act physically is recognized, the acts of its agents are attributed to it. The corporation is then treated as a human actor. Where the act is the practice of medicine, the corporation itself is said to practice and, being unlicensed, is held guilty of violating the licensure acts. ${ }^{85}$ The flaw in this reasoning lies in its anthropomorphism. The law does not attribute the acts of a human being to that legal construct, the corporation. Instead, it imputes the legal consequences of such acts to the corporation. If a corporate agent's act is wrongful, its legal consequence-the liability prescribed for that wrong-will be imposed on the corporation, so far at least as the

\footnotetext{
${ }^{82}$ Nor is the classification the only possible one: a distinction may be based on the absence or presence of payment by the patient. The requirements placed on medical service will be strict where the patient pays full or partial compensation, the recipient of charity will have to take what is tendered to him.

${ }^{88}$ Cf. Texas and Pac. Coal Co. v. Connaughton, 20 Tex. Civ. App. 642, 50 S. W. 173 (1899); Owens v. Atl. Coast Lumber Corp, 208 S. C. 528, 94 S. E. 15 (19r7).

s' The suggested classification has significance beyond the formal field of corporate organizations. The types of "third interest" will recur with the same implications regardless of the organizational form. Cf. Ezell v. Ritholz, I88 S. C. 39, I98 S. E. 419 (1938) (partnership may not practice optometry). Cf. also Princtples of Medical Etrics, supra note 2, c. $1, \$ 2$ (Groups and Clinics): "The ethical principles actuating and governing a group or clinic are exactly the same as those applicable to the individual. As a group or clinic is composed of individual doctors, each of whom, whether employer, employee or partner, is subject to the principles of ethics, herein elaborated, the uniting into a business or professional organization does not relieve them either individually or as a group from the obligation they assume when entering the profession."

${ }^{3 s}$ Cf. Winslow v. Kansas State Bd. of Dental Examiners, I 55 Kan. 450, 223 Pac. 308 (I924). "... that a corporation cannot stand up on its hind legs before a board of bar examiners and recite the rule in Shelley"s case . . . is true, but meaningless. . . ." Weihofen, "Practice of Law" by Non-pecuniary Corporations: a Social Utility (I934) 2 UNIV. CrI. L. REV. Irg, I29.

In an alternative analysis it would be admitted that those corporations where the position of the cmployed physician is relatively unimpaired, practice medicine but that they are not within the purview of the licensure statutes or enjoy a privilege to practice without license provided their employees are licensed.
} 
sanction is susceptible of application to a corporation. If the agent's act is rightful, there is no liability consequent upon it to be imposed on the corporation. Instead, the act may create a right or privilege, the benefit of which may, by imputation, be enjoyed by the corporation.

Under this correct analysis, it will be seen that there is no occasion for the use of the term "corporate practice." The problem becomes instead whether the practitioner agents of a corporation furnishing medical services have engaged in unprofessional conduct by assuming obligations which weaken ethical restraints or result in improper delegations of responsibility to lay agents. This inquiry leads directly to an examination of the purposes and organization of the corporation subject to attack. If, as, for example, in most corporations of the first and second types, no conduct by professional and lay agents which is improper in this sense is found, then there will be no violation of the licensure acts to be imputed to the corporation. But where, as in most commercialized enterprises, the set-up threatens professional safeguards, violation of the licensure acts by the corporate agents may be found and imputed to the corporation.

In turning to the decisions which seem to have denied categorically to corporations the right to practice medicine, ${ }^{36}$ an observation should be made. Most of the decided cases do not involve medicine proper, but relate to the practice of dentistry ${ }^{37}$ and optometry ${ }^{38}$ by corporations admittedly organized for profit, the third type in the classification. Is it surprising to find the courts applying a broad rule without nice distinctions, when they strike down these commercial ventures, especially where the corporate cloak hides quackery? Thus, a dentist changing his first names from Edgar Randolph to "Painless," and operating a complex network of "Painless Parker System" corporations, has furnished a much quoted cluster of precedents. ${ }^{30}$ Decisions involving directly the right to practice medicine within a corporate framework are relatively rare. Yet here, too, most of the decided cases present a rather uniform pattern: profit organizations with the streak of quackery. Institutes for cancer treat-

\footnotetext{
${ }^{88}$ Supra note 29.

${ }^{87}$ Dentistry is distinguishable from medicine by its narrow field,' rather uniform treatment, lesser seriousness of the "disease." These factors, and the relatively recent discovery by the public of the importance of dental care for health generally may account for belated admission of dentistry to the "professional sanctum." With a professional ethos less strongly developed, reported excursions into commercial fields are, accordingly, more frequent.

${ }^{38}$ The same distinction may be made for optometry, an occupation to which some courts deny professional character. Consultation of an optometrist may be viewed as a necessary preliminary or anncx to a sales transaction. The commercial tinge is more pronounced and the reported cases revolve around a rather uniform fact situation: independent optometrists verstus the department store employing a liecnsed optometrist or leasing a department to another optometrical entrepreneur maintaining chains of such leased departments.

${ }^{30}$ Parker v. Bd. of Dental Examiners, 29I Pac. 42I (Cal. App. 1930); Parker v. Bd. of Dental Examiners I P. (2d) 50I (Cal. App. 193I); Parker v. Bd. of Dental Examiners, 216 Cal. 285, 14 P. (2d) 67 (1932); People v. Painless Parker Dentist, 85 Colo. 304, 275 Pac. 928 (r929); People ex rel. Mahurin v. State Bd. of Dental Examiners, 85 Colo. 32x, 275 Pac. 933 (1929); State Bd, of Dental Examiners v. Savelle, 9o Colo. 177, 8 P. (2d) 693 (1932); State Bd. of Dental Examiners v. Miller, 90 Colo. 193, 8 P. (2d) 699 (1932); see "Painless Parrmer, Inc." in Rust v. State Bd. of Dental Examiners, 216 Wis. 127, 256 N. W. 919 (1934).
} 
ment with secret fluids and powders, ${ }^{40}$ for liquor habits, ${ }^{41}$ organizations where the treatment is part of a sales scheme for pharmaceutical products ${ }^{42}$ are eliminated by judicial veto.

The second and first types of corporations present a different picture. The first is notably absent: no reported cases have been found where courts have directly prevented corporate practice by charitable or educational institutions, industry or railroads. On the contrary, occasional dicta evidence judicial tolerance. ${ }^{43}$ The latest arrival in this group, the non-profit cooperative patient or "consumer" organizations, has received explicit judicial sanction so far in one case, recently decided in Washington, D. C. ${ }^{44}$ No cases have been found directly ${ }^{45}$ challenging the second group: corporations formed by physicians practicing in groups. This is not surprising as the policy arguments against them are less weighty. It may be assumed that they will acquire a similar "prescriptive right to exist" as has been accorded the various charitable and paternalistic organizations enumerated under the first group.

As the new forms of practice spread, the courts will have further occasion to reconsider the broad maxim condemning all corporations alike. It served satisfactorily in the past when it was exclusively invoked against anti-social activities, but its sweep becomes oppressive today as it threatens desirable experimentation. Until the legislatures have spoken explicitly, it is important that the courts exercise a nice discrimination in dealing with new forms of corporate organization in the medical field.

${ }^{10}$ State v. Baker, 212 Iowa 57I, 235 N. W. 313 (1931); State v. Baker, 222 Iowa 903, 270 N. W. 359 (1936).

${ }^{11}$ Godfrey v. Medical Society of N. Y. County, 177 App. Div. 684,164 N. Y. Supp: 846 (1917).

42 People ex rel. Lederman v. Warden, I68 App. Div. 240, 152 N. Y. Supp. 977 (I915); State v. Heffernan, 28 R. I. 20,65 Atl. 284 (1906).

${ }^{13}$ See People ex rel. State Bd. of Med. Examiners v. Pacific Health Corp., I2 Cal. (2d), 156, 157, 82 P. (2d) 429, 43x (1938); People v. John H. Woodbury Dermatological Institute, 192 N. Y. 454, 85 N. E. 697 (1908); Goldwater v. Citizens Casualty Co. of N. Y., 7 N. Y. Supp. (2d) 242, 248 (I938). Malpractice suits against industrial corporations or railroads have been denied by classifying the employed physician as an "independent contractor." The restriction of corporate liability to cases where the employing corporation acted negligently in selecting the physician is, in effect, a judicial encouragement of this form of practice. See Note, Liability of Hospital for Injuries to Patients using Hospital Facilities (1938) 48 YALE L. J. 81, 90; Metzger v. Western Ry., 30 F. (2d) 50 (C. C. A. 4th, 1929); Pearl v. West End Street Ry., I76 Mass. I77, 57 N. E. 339 (I900).

"Group Health Ass'n v. Moor, supra note 3 .

${ }^{45}$ Cf. Iterman v. Baker, 15 N. E. (2d) 365 (Ind. 1938); Johnson v. Stumbo, 277 Ky. 301, I26 S. W. (2d) 165 (1938); Daly's Astoria Sanatorium v. Blair, I61 Misc. 716, 291 N. Y. Supp. I006 (1936); Tarry v. Johnston, II4 Neb. 496, 208 N. W. 615 (1926). Cf. also State ex inf. Sager v. Lewin, 128 Mo. App. I 49, 106 S. W. 581 (I907) for judicial toleration of a "Hernia Cure Co" under professional control; Chenoweth v. State Bd. of Medical Examiners, 57 Colo. 74, I4I Pac. 132 (1913). 